injection of local anaesthetic and a short period of observation before the injection of retrobulbar alcohol is highly recommended.

1 Ahn JC, Stanley JA. Subarachnoid injection as a complication of retrobulbar anesthesia. Am F Ophthalmol 1987; 103: 225-30.

2 Hamilton RC, Gimbel HV, Strunin L. Regional anaesthesia for 12000 cataract extraction and intraocular lens implantation procedures. Can $\mathcal{f}$ Anaesth 1988; 35: 615-23.

3 Zahl K, Nassif JM, Meltzer MA, Som P. Simulated peribulbar injection of anaesthetic. Ann Ophthalmol 1991; 23: bulbar

4 Al-Faran MF, Al-Omar OM. Retrobulbar alcohol injections in blind painful eyes. Ann Ophthalmol 1990; 22: 460-2. 5 Maumenee AE. Retrobulbar alcohol injections. Relief of ocular pain in eyes with and without vision. Am $\mathcal{f}$ Ophthalmol 1949; 32: 1502-8.

\title{
Intravitreal chemotherapy for recurrent retinoblastoma in an only eye
}

\author{
Stefan Seregard, Erik Kock, Eva af Trampe
}

Recurrent retinoblastoma in the only remaining eye presents a distressing dilemma to both the patient and physician. After the failure of conventional treatments, enucleation has until now been the only option left. However, some previous results suggest that intraocular chemotherapy using the alkylating agent thiotepa may be beneficial in the treatment of retinoblastoma. ${ }^{1}$ Furthermore, an early toxicity study in rabbits indicates that thiotepa may be administered intravitreally in concentrations up to $20 \mathrm{mg}$ per $\mathrm{ml}$ before transient vitreal clouding occurs. ${ }^{2}$ In the cases reported here, the rationale included the use of intravitreal chemotherapy to induce tumour death and vitrectomy for subsequent removal of necrotic tissue. The aim was to retain the only remaining eye in recurrent retinoblastoma with extensive vitreous seeding without causing extraocular tumour recurrence or metastatic disease.

\section{Case reports}

One boy and two girls aged $2 \cdot 5,4 \cdot 5$, and 18 months presented with bilateral retinoblastoma. In all patients, one eye was enucleated and the remaining eye was treated with 4500 cGy external beam radiotherapy (all cases), irradiation with a cobalt-60 applicator (one case), the multicobalt Leksell gamma knife (one case), cryotherapy (two cases), and argon laser photocoagulation (one case). In all patients, multiple tumour recurrences with extensive vitreous seeding eventually suggested that the remaining eye had to be enucleated.

However, after careful evaluation and informed parental consent, repeated injections of $2 \mathrm{mg}$ thiotepa dissolved in $0.5 \mathrm{ml}$ of balanced salt solution were delivered intravitreally through a pars plana approach and a small amount was left subconjunctivally at the injection site. The injections were repeated twice in 2 weeks before standard three port pars plana vitrectomies were performed. Following surgery, supplemental thiotepa injections were continued on a weekly basis until a total of $10 \mathrm{mg}$ thiotepa (two cases) or $14 \mathrm{mg}$ thiotepa (one case) had been delivered.

No obvious clinical response was noted in any eye before vitrectomy. One of the girls had all vitreous seeding removed, but retained one small tumour in the peripheral retina after vitrectomy. However, this residual growth turned gelatinous during the post-vitrectomy thiotepa injections. After the cessation of intraocular chemotherapy, the same girl underwent an extracapsular cataract extraction with an intraocular lens implant and now experiences $20 / 20$ visual acuity. The other girl had two additional vitrectomies because of initial incomplete tumour removal and cytological examination of her vitreous washings confirmed the presence of retinoblastoma cells. After her final vitrectomy, only a few strands of tumour tissue remained adherent to the optic disc. These small remnants also turned gelatinous following the post-vitrectomy chemotherapy. Her visual acuity is now $20 / 400$ as a result of previous tumour growth of the macula in conjunction with a moderate subcapsular cataract. The boy had more extensive retinal growth as well as considerable vitreous deposits and vitrectomy failed to remove substantial parts. A few days after surgery he suffered a major vitreous haemorrhage and 1 month later the eye was enucleated. Histopathological examination of the globe revealed nearly all tumour tissue to be necrotic, but the vitreous contained some retinoblastoma cells that appeared viable. No mitotic figures were present, but positive immunostaining for the proliferating cell nuclear antigen in a few tumour cells suggests that these cells maintained a proliferative potential. There are no signs of local recurrence or metastatic disease after follow up periods of 14 (girl with 20/20 visual acuity), 70 (boy), and 77 months (girl with 
20/400 visual acuity) after intravitreal chemotherapy.

\section{Comment}

Earlier work suggests that plaque radiotherapy may be advantageous in recurrent retinoblastoma with localised vitreous seeds. ${ }^{3}$ However, all three children in this study had considerable vitreous seeding and plaque radiotherapy was not performed. Systemic chemotherapy for retinoblastoma usually employs more potent drugs that thiotepa. In the current study, the intravitreal approach required an agent that caused tumour cell death with a minimum of toxicity and thiotepa was chosen because of previous findings. ${ }^{12}$ The use of any intraocular procedure in an eye with retinoblastoma entails an increased risk of subsequent extraocular extension. ${ }^{4}$ Therefore, combined intravitreal chemotherapy and vitrectomy is probably best withheld for recurrent retinoblastoma with widespread vitreous seeding in an only eye and extreme caution is advised. In each case the benefit of saving the remaining eye would have to be weighed against the risk of causing tumour spread.

Presented in part at the International Symposium of Intrabulbar and Epibulbar Tumours, 3-5 March 1994, Florence, Italy.

1 Ericson L, Rosengren BHO. Present therapeutic resources in retinoblastoma. Acta Ophthalmol (Copenh) 1961; 39: 569-76.

2 Ericson L, Karlberg B, Rosengren BHO. Trials of intravitrea injections of chemotherapeutic agents in rabbits. Acta Ophthalmol (Copenh) 1964; 42: 721-6.

3 Shields CL, Shields JA, De Potter P, Minelli S, Hernandez C, Brady LW, et al. Plaque radiotherapy in the management of retinoblastoma. Use as a primary and secondary ment of retinoblastoma. Use as a primary and

4 Stevenson KE, Hungerford J, Garner A. Local extraocular extension of retinoblastoma following intraocular surgery. Br f Ophthalmol 1989; 73: 739-42. 